DOI 10.37882/2223-2982.2020.07.07

\title{
К ВОПРОСУ О ВОСПИТАНИИ МОЛОДЕЖИ: РОССИЙСКИЙ АСПЕКТ
}

\section{ON THE ISSUE OF YOUTH EDUCATION: THE RUSSIAN ASPECT}

\section{Bi Qiushuang}

Summary: Today's young people represent the future of the country, so their education is one of the most important issues facing the state, so it is important to use all available resources to ensure that true values are in the first place in society, young people know and appreciate the traditions, understand and respect the history of the country. To do this, it is necessary to understand the theoretical aspects of youth education, which is the subject of this article.

Keywords: the education of the younger generation, the concept of upbringing of viable generations, patriotic education.
А.С. Макаренко в своей работе «Педагогические сочинения» писал о воспитании: «... есть процесс социальный в самом широком смысле. Воспитывает всё: люди, вещи, явления, но прежде всего - люди... Со всем сложнейшим миром окружающей действительности ребенок входит в бесконечное число отношений, каждое из которых неизменно развивается, переплетается с другими отношениями, усложняется физическим и нравственным ростом самого ребенка» [1]. Хотя здесь А.С. Макаренко говорит о детях, это его высказывание в полной мере относится и к молодёжи в целом. При этом надо понимать, что воспитание не является отдельно протекающим процессом, это совокупность многих параллельных и взаимосвязанных процессов, социализирующих молодого человека, направленных на становление его личности, обретения своего места в жизни, социального и профессионального самоопределения. Проблемы воспитания на протяжении многих веков, изучали многие исследователи, от Аристотеля до А.С. Макаренко и К.Д. Ушинского, от Френсиса Бэкона до Карла Роджерса. Указанные ученые рассматривали воспитание в философском и прикладном аспектах. Это обуславливается тем, что эта проблематика чрезвычайно значима и для самих молодых людей, и для общества в целом. Здесь существенны два основных фактора:

- во-первых, без овладения социальными ролями молодежь не может само идентифицироваться в социальной жизни и реализовать свою субъектность;

- во-вторых, в силу того, что, молодежь является источником и резервом для стабильного культурно-
Би Цюшуан

Аспирант, Северо-Восточный федеральный университет имени М.К. Аммосова, Якутск 1650518521@qq.com

Аннотация: Сегодняшняя молодежь представляет собой будущее страны, поэтому ее воспитание является одним из важнейших вопросов, который стоят перед государством. Важно задействовать все имеющиеся ресурсы, чтобы в обществе на первом месте стояли истинные ценности, молодежь знала и ценила традиции, понимала и уважала историю страны. Для этого необходимо понимать теоретические аспекты воспитания молодежи, чему и посвящена данная статья.

Ключевые слова: воспитание, молодое поколение, концепции воспитания жизнеспособных поколений, патриотическое воспитание.

го, научного и производственно-экономического развития страны, то проблематика ее воспитания и социализации приобретает исключительную важность.

Логически обоснованная политика воспитания молодёжи должна учитывать влияние общественного уклада и культуры на восприятие молодежью окружающего социума в частности, и мира в целом, что отражается в ее поведении. Непродуманность деятельности в этой сфере может привести к равнодушию к ценностям общества, рождая цинизм, эгоцентризм, безнаказанность и безжалостность [2]. Поэтому проблема устранения отрицательного воздействия на современную молодежь должна носить комплексный и системный характер, основанного на всем спектре возможных к использованию методов и социально приемлемого инструментария.

В Российской Федерации разработан закон «Основы государственной молодежной политики до 2025 года», который устанавливает тактические и стратегические мероприятия, сконцентрированные на борьбе с отрицательными аспектами в системе воспитания молодежи. Вместе с тем, необходимо учитывать и то, что современные социально-экономические и политические реалии существенно изменили как теоретические и практические подходы и методы воспитания как отдельной личности, так и молодежи как социальной группы. В данной статье рассматриваются некоторые исследования по трем направлениям проблематики воспитания молодежи (см. табл. 1). 
Таблица 1

Основные направления воспитания молодежи в современных условиях

\begin{tabular}{|l|l|}
\hline Проблематика & Исследователи \\
\hline $\begin{array}{l}\text { Вопросы воспитания студенческой } \\
\text { молодежи }\end{array}$ & $\begin{array}{l}\text { Антонова Л.Н., Зубова Е.И., } \\
\text { Меренков А.В., Ушамирская Г.Ф. } \\
\text { и др. }\end{array}$ \\
\hline $\begin{array}{l}\text { Разработка и обоснование концеп- } \\
\text { ции воспитания жизнеспособных } \\
\text { поколений }\end{array}$ & $\begin{array}{l}\text { Бабочкин П.П., Ильинский П.М. } \\
\text { и др. }\end{array}$ \\
\hline Патриотическое воспитание & $\begin{array}{l}\text { Бузский М.П., Вырщиков А.Н., } \\
\text { Кусмарцев М.Б. и др. }\end{array}$ \\
\hline
\end{tabular}

Меренков А.В., Рыбцова Л.Л. и Кольцова В.А. в своем исследовании утверждают, что современная эпоха требует от человека значительных адаптивных свойств, постоянного расширения знания и навыков как для приспособления к современному духовному и научно-техническому развитию, так и деятельно создавать новые конфигурации своей жизни. Это можно выработать только при соответствующем изменении форм и содержания общественного и семейного воспитания. Стихийно эти изменения не свершатся, а значит здесь необходима особая работа по формированию современной системы воспитания [3]. По их мнению еще не все понимают значение предстоящих преобразований и основывают свою деятельность в данной сфере по устаревшим стереотипам, что, безусловно, сдерживает реализацию необходимых трансформаций в системе организации воспитания нового поколения. Это неминуемо приведет к возрастанию отрицательных тенденций в молодежной среде. Поэтому, то общество, которое сможет реорганизоваться, сможет не формально, а реально создать условия для новых поколений по овладению требований будущей эпохи.

Антонова Л.Н. и Зубова Е.И. выделяют в отдельную проблему воспитательную работу с «трудной молодежью». По их мнению, эта категория требует очень деликатного отношения к ним общества и государственных органов. Здесь необходимо включать молодежь в разнообразную трудовую и образовательную и деятельность, что должно обеспечить восстановление расстроенных социальных взаимосвязей с обществом, формирование способности противостоять асоциальным рецидивам, освоение социально-одобряемых и предотвращение негативных форм поведения [4].

Но, требуя от молодого поколения принятия социально-ролевых правил общества, государство и общество должны сами, по мнению Ушамирской Г.Ф., сформировать свой взгляд в отношении сущности последних [5]. Это обусловлено тем, что отсутствие ясности эталонов и норм поведения приводит как к хаосу и неопределенно- сти в сознании молодежи, так и к кризису социального доверия.

Поэтому Ушамирская Г.Ф. обоснованно полагает, что необходимо определить конвенциональные рамки для установления структуры социальных ролей, которые должны основываться с учетом приоритета характеристик, объединённых с будущей перспективой социального статуса современной молодежи. Практика, когда роли молодых людей рассматриваются в ситуативно, и как следование текущим поведенческим нормам, исторически ограниченна и ошибочна, так как не обеспечивает эффективную и результативную адаптацию в условиях развития современного общества.

Бабочкин П.И. исследовал вопрос жизнеспособности молодежи в изменяющемся обществе [6]. По его мнению, жизнеспособность человека как социального индивида значит то, что он может выжить как социально, так и биологически в условиях конкретной природной и социальной среды, произвести жизнеспособное в психическом и физическом плане потомство, социализировать его в обществе. Жизнеспособность полагает как адаптацию к социальной и природной среде, так и активность как члена социума, нацеленную на реорганизацию социоприродной среды для развития общества и личности. Помимо этого, жизнеспособность конкретного индивида предполагает, что он сможет выработать свое понимание смысла жизни, ее цели, раскрыть и развить свои способности, воплотить в жизнь свой творческий потенциал. В целом Бабочкин П.И. делает вывод о том, что одной из важнейших задач воспитания молодежи в современных реалиях российского общества должно быть формирование ее жизнеспособности и социально-психологической устойчивости.

Ильинский И.М. в своей концепции воспитания жизнеспособного поколения предлагает систему воспитания, включающей два основных уровня [7].

1. Первый уровень - стратегический, фундаментальный, который формирует основные качества, определяющие жизнеспособность личности в современной России. Ильинский И.М. обосновывает это тем, что Российское общество значительно дифференцируется и по источникам доходов, и по уровням благосостояния, а также по отношению к собственности, и здесь необходимо:

- во-первых, формировать и поддерживать те идеалы и ценности, которые могут привести к национальному консенсусу;

- во-вторых, предоставить для вновь образующихся стратов населения возможность создания своих ценностей. Совместное применение двух этих принципов поможет формировать стержневые ценности у молодежи с учетом возможностей всех 
существующих методов и средств воспитания и, при этом, сохранит прозрачность и открытость системы воспитания, избегая очередного фанатизма или заблуждения. Таким образом, стратегический уровень формирует:

- единый подход к формированию молодого человека, его способностей, воспитания гражданина, постижения ценностей и достижений национальной и общечеловеческой культуры;

- систему восприятия и оценки молодым человеком духовных и материальных явлений культуры и жизни с тех позиций, которые определены системой воспитания.

2. Второй уровень системы воспитания, предложенной Ильинским И.М., направлен на уровень разнообразных социальных групп и слоев общества. Здесь необходимо существенная диверсификация вариативности форм, методов и содержания воспитания в самих структурах системы воспитания. Если на стратегическом уровне складываются общие гражданские качества и способности личности, необходимые любому представителю молодежи, то на втором уровне вырабатываются специфические способности, личностные качества, мировоззренческие воззрения и морально-этические убеждения в зависимости от требований той или иной социальной группы к конкретной личности, к пониманию и принятию ценностей группы, ее традиций, интересов и целей. Вариативность второго уровня в концепции системы воспитания Ильинского И.М. позволяет формировать и другие аспекты личности, например: воспитание в вопросах семьи и брака, воспитание по уровню возрастных групп молодежь и т.п.

В области патриотического воспитания молодежи исследования в основном сконцентрированы на выявление методов формирования у молодого поколения мировоззрения гражданина и патриота, а также снижения степени влияния негативных духовных и идеологических воздействий. В современной общественной жизни практика и теория патриотического воспитания молодого поколения переживает серьезные изменения, и все более явственна недостаточность традиционных методов и подходов по решению задач и функций патриотической работы, а также косность формализма, проявляющегося прежде всего в увлеченности парадными массовыми мероприятиями и др. Данной проблематикой, занимались в разное время множество отечественных и зарубежных исследователей. Рассмотрим работы некоторых из советских и российских авторов.

Вырщиков А.Н., Кусмарцев М.Б. считают, что необходимыми условием для всестороннего воспитания патриотизма является формирование высокого уровня морально-психологического климата социума, повышение уровня общественной активности разных социальных групп и слоев. Это должно реализовываться посредством роста эффективности и результативности деятельности не только средних и высших учебных заведений и органов власти, но и предприятий и организаций, учреждений культуры и др.

Бузский М.П. замечает: «Субъект, это такой уровень личности и общества, при котором для него возникает мир, так как субъект способен проектировать (определять, выделять) соответствующий ему объект. Несмотря на то, что мир существует и без субъекта, как определенный объект, который может обнаружить и раскрыть свои качества, он существует лишь в отношении к субъекту и через него. Это значит, что если народ становится субъектом, то содержание данного общества уже не оторвано от него, не отчуждено, а согласовано с самими свойствами субъекта - его целями, потребностями, интересами, ориентирами. Народ как субъект выражает не состояние и не ситуацию, в которой он находится, но коренные свойства бытия самого общества» [9]. По его мнению, воспитывать молодежный патриотизм - это означает предоставить свободу жизненным интересам молодого человека, способствующим его личностному развитию, через формирование определенного социального вектора, создание связи с жизненными ценностями предыдущих поколений, как базы патриотической жизненной позиции.

В целом, исследования указанных авторов, приводят к схожим выводам: государству и обществу требуется новая и не раздробленная узкогрупповыми интересами система ценностей, основанная на традициях российского социума и отвечающая современным и перспективным целям, которая позволит сконцентрировать усилия и ресурсы всего народа на пути к благоденствию. Это может быть и честная конкуренция, и добросовестный труд, и сознательная законопослушность. И именно такой взгляд на рассматриваемую проблему показывает важность поиска путей и методов созидательного осуществления воспитания молодежи как одного из важных направлений деятельности федеральных, региональных и муниципальных органов, формирующих государственную политику для укрепления государства, консолидации всего общества и повышения качества жизни его граждан.

В этом аспекте для совершенствования воспитания необходимо более тщательно осмыслить его сущность, цели и задачи. Соответственно методы и средства воспитания молодежи должны быть: во-первых, связаны с процессом ее гражданского становления; во-вторых, иметь специфические подходы, предполагающие моделирование различных обстоятельств процесса воспитания, учитывающие патриотические основы и ценностные ориентации. 
В целом, при совершенствовании воспитания молодежи, по мнению российских исследователей, следует использовать все составляющие образовательно-воспитательного пространства:

а) цели, адекватные структуре готовности к служению Родине, соответствующие разным возрастным группам;

б) содержание, где ясно определены понятия и категории, мировоззренческие идеи и общечеловеческие ценности, которые в совокупности будут содействовать развитию убеждений и знаний в важности служения Отечеству, тесно связанных с ценностными ориентирами и установками личности;

в) методы воспитания должны учитывать сформированные потребности, интересы и ценностные ориентации молодого поколения, его коммуникативные и психологические характеристики и осо-

\section{бенности;}

г) современные возможности процесса воспитания, где сегодня значимую роль представляет групповая работа, моделирующая ситуации социальнообщественных процессов, которые способствуют более глубокому и личностному восприятию исторических, национальных и международных событий в многовековой истории страны, стратегических перспектив ее развития;

д) систему подготовки организаторов и исполнителей процесса воспитания.

Таким образом, воспитание молодежи должно основываться на тщательном изучении жизни молодого поколения, выявление всего спектра их ценностных ориентаций, что невозможно осуществить без глубокого анализа информации, основывающегося на «реперных точках» адекватных этим ориентациям форм поведения.

\section{ЛИТЕРАТУРА}

1. Макаренко, А.С. Педагогические сочинения. Т. 5. / А.С. Макаренк. - М.: Педагогика, 1985. - С. 14.

2. Byrnes, J.P. Naive theories and decisionmaking as part of higher order thinking in social studies / J.P. Byrnes, J.V. Torney-Purta // Theory and Research in Social Education. - 1995. - Vol. 23 (3). - P. 260-277.

3. Меренков А.В., Рыбцова Л.Л., Кольцова В.А. Семейное воспитание: кризис и пути его преодоления / Екатеринбург: Изд-во Уральского государственного университета. - 1997. - 105 с.

4. Антонова Л.Н., Зубова Е.И. Воспитание в условиях социального многообразия: взаимодействие семьи и школы // Асаdemia. Педагогический журнал Подмосковья. 2016. № 4 (10). С. 3-8.

5. Ушамирская Г.Ф. Интернализация социальных ролей учащейся и студенческой молодежи. — Волгоград: Изд-во ВолГУ, 2002.

6. Бабочкин П.И. Становление жизнеспособной молодежи в динамично изменяющемся обществе. Москва. - 2000. - 175 с.

7. Ильинский И.М. Молодежь России: воспитание жизнеспособных поколений: докл. Ком. РФ по делам молодежи / авторский коллектив : Ильинский И. М. [и др.] ; Ком. РФ по делам молодежи. - М. : [6.и.], 1995. - 256 с.

8. Вырщиков А.Н., Кусмарцев М.Б. Патриотическое воспитание молодёжи в современном российском обществе / Монография. - Волгоград: НП ИПД «Авторское перо», 2006. - 172 с.

9. Теоретические проблемы патриотизма и патриотического воспитания : монография / М.П. Бузский, А.Н. Вырщиков, М.Б. Кусмарцев ; М-во образования и науки Российской Федерации, Гос. образовательное учреждение высшего проф. образования «Волгоградский гос. ун-т». - Волгоград : Изд-во ВолГУ, 2008. -90 c.

(c) Би Цюшуан (1650518521@qq.com). 